\title{
THE IMPACT OF TRANSLANGUAGING APPROACH ON TEACHING ARABIC READING IN A MULTILINGUAL CLASSROOM
}

\author{
Saidna Zulfiqar Bin-Tahir, Ummu Saidah, Nuril Mufidah, Riki Bugis \\ Universitas Iqra Buru Maluku, IAIN Ambon, UIN Maulana Malik Ibrahim Malang, \\ Universitas Iqra Buru Maluku \\ Email: saidnazulfiqar@gmail.com, ummusaidaharief@gmail.com, \\ nurilmufidah86@uin-malang.ac.id, rikibugisuniqbu@gmail.com
}

\begin{abstract}
:
The study aimed at measuring the effect of translanguaging approach in teaching Arabic reading comprehension to the second semester students of Indonesian Education Department, Universitas Iqra Buru. 64 students involved as the participants through simple random sampling technique. 32 students participated in each of the experimental and control group. The researchers used reading test of written test to obtain information about the students' achievemnt in reading on the use of translanguaging approach and it was distributed to the respondents after the last treatment given. To find out the mean score, standard deviation and the t-test value between the pretest and the posttest the researchers used the SPSS 17 program. The researchers found that the use of translanguaging approach in learning Arabic reading comprehension improves the students' ability of Arabic reading comprehension is better than the conventional method.
\end{abstract}

Keywords: Arabic teaching; reading comprehension; translanguaging; multilingual

\section{A. INTRODUCTION}

In the context of an increasingly globalized world, interactions among nations that impact on language, cultural, and even ideological interactions become unavoidable (Bin Tahir, 2015; Bin-Tahir \& Rinantanti, 2016; Duarte, 2016; Amri et al., 2017). As a result of contacts at the level of language, there are opportunities in which a foreign language color and even dominates the language of the language (especially heritage language), especially in certain contexts such as the use of key terms, scientific discussions, and so on. Being on the cultural level, there is acculturation that combines the dimensions of cultural origin with local language that exists (Saputra \& Atmowardoyo, 2015). Meanwhile, cultural and linguistic contacts may continue in ideological interactions affecting the behavior or typology of educational patterns (Irwansyah, 2013; Tahir, 2015; Wei, 2017).

Indonesia is a multicultural country, because it consists of various cultures, customs, and habits. These components are generally bonded together (integrated/embedded) with ethnicity, language, and culture (Bin-Tahir et al., 2017; Edi et al., 2017; Abubakar et al., 2017). Some previous researchers have studied the method, strategy, and approach in teaching the foreign language in Indonesia (Bin-Tahir \& Hanapi, 2017; Abubakar et al., 2017) but they did not study yet the use of translanguaging approach. The use of foreign languages, especially Arabic, is in its forms related to the teaching of foreign languages in formal and informal education in Indonesia. Even some foreign languages have been taught in some universities, 
including the obligation of learning Arabic for every student at Iqra Buru University, Maluku. This obligation inspired the researchers to conduct a study to measure the effectiveness of translanguaging approach on teaching Arabic reading in multilingual classroom. This study expected to give contribution for the further researcher in this field of study, especially in multilingual teaching and learning.

\section{B. REVIEW OF LITERATURE}

\section{Translanguaging}

The term translanguaging seems to have captured people's imagination. It has been applied to pedagogy, daily social interaction, cross-modal and multimodal communication, linguistic landscape, visual art, music, and transgender discourse. The growing body gives the impression that any slightly non-conventional practice can be explained in terms of Translanguaging Wei, 2017).

Tanslanguaging is the process by which multilingual speakers use their language as an integrated communication system (Canagarajah, 2011). It is a dynamic process in which multilingual language users mediate complex social and cognitive activities through the strategic work of various sources of semiotics for action, to know and be (Garcia \& Wei, 2014). Translanguaging involves issues of language production, effective communication, the function of language, and the thought processes behind language use (Lewis et al., 2012).

\section{Multilingual}

Multilingual has played an important role in globalization era as a tool to drive competitiveness among people or countries over the world, such in the economy, trade, policy, culture, and also education. It was defined ordinarily as the ability to speak or to communicate using three or more languages (McArthur, 1992; Edwards, 1994; Vildomec, 1963; Kemp, 2009). According to Li Wei and Moyer (2008), multilingual individual is anyone who can communicate in more than two languages, be it active (through speaking and writing) or passive (through listening and reading).

Multilingual is a considerable number of people who can speak more than two languages in their everyday life due to some interaction reasons (Cenoz, 2002; Herdina \& Jassner, 2000). Besides, Cruz-Ferreira (2010) stated that multilingual is not about what several languages can do for people but what about people can do with several languages. Therefore, the multilingual people in this study refer to the ability of a person to speak and communicate actively using three or more languages in a circumstance or in an occurrence of the communication and not in separate circumstances (Bin-Tahir et al., 2017).

\section{Reading}

Reading is a combination of mechanics, understanding, retention, and use. In this broadest of the three views, the reader should be able not to perform the mechanics and comprehend the meanings of the words, but to critically evaluate the ideas expressed and apply them to his or her situation Carillo (1976). According to Hornby (1995), reading is a way in which something is interpreted or understood. While Harmer (1991) defines reading is an exercise dominated by the eyes and the brain. The eyes receive messages and the brain then has to work out significance of these messages.

Reading is about understanding written texts. It is a complex activity that involves both perception and thought. Reading consists of two related processes: word 
recognition and comprehension. Word recognition refers to the process of perceiving how a written symbols correspondent to one's spoken language. Comprehension is the process of making sense of words, sentences and connected text. Readers typically make use of background knowledge, vocabulary, grammatical knowledge, experience with text and other strategies to help them understand written text (Pang et al., 2003).

In 2000, the National Reading Panel (NRP) issued a report that identified five areas that they found critical for components of effective reading instruction: 1) Phonemic awareness, 2) Phonics, 3) Fluency, 4) Vocabulary, and 5) Comprehension.

\section{METHOD}

This research applied quantitative approach using quasi-experimental design in collecting the data and to analysing the data. The design involved two groups, namely experimental group and control group. The experimental group was taught by using translanguaging approach while the control group used conventional method or without applying translanguaging in learning process (Gay, 2006). Both of the two groups were given pre-test and post-test. Pre-test was administered before the treatment to asses the students' prior knowledge on reading skill and the post-test administered after treatment. The aim of this test was to find out the effectiveness of translanguaging approach in teaching reading.

The population of the research was the second semester students of Indonesian Education Department, Universitas Iqra Buru in academic year 2016/2017. It had four classes with the number of population is 93 students. Since the number of population was large, the researchers used simple random sampling technique. One class was chosen as the experimental group and one class for control group. The number of sample for every group was 32 students. So, the total number of sample was 64 students.

The researchers used reading test as written test. The test was used as pretest and posttest by using objective tests. It consists of 30 items; there were 10 questions for Literal category, 10 questions for inferential category, and 10 questions for Comprehensive. The pretest was given to the students before the treatment and the posttest was given after treatment in order to check their reading achievement. The test was used to obtain information about the students' aachievemnt in reading on the use of translanguaging approach and it was distributed to the respondents after the last treatment given.

To analyze the test result, the researchers used the descriptive analysis to know the percentage of the students' reading achievement through translanguaging approach. To find out the mean score, standard deviation and the t-test value between the pretest and the posttest the researchers used the SPSS 17 program (Gay, 2006).

\section{RESULTS}

The frequency score and the percentage of the students' reading comprehension both experimental and control group in pretest can be seen in the following tables.

Table 1: The Frequency and Percentage of the Students' Reading Comprehension Achievement in Pretest.

\begin{tabular}{cccccc}
\hline Classification & Range of score & \multicolumn{2}{c}{ Experimental Group } & \multicolumn{2}{c}{ Control Group } \\
\hline & & $\mathrm{F}$ & $\%$ & $\mathrm{~F}$ & $\%$ \\
\hline Excellent & $96-100$ & 0 & 0 & 0 & 0 \\
\hline
\end{tabular}




\begin{tabular}{lccccc}
\hline Very good & $86-95$ & 0 & 0 & 0 & 0 \\
Good & $76-85$ & 0 & 0 & 0 & 0 \\
Fairly good & $66-75$ & 0 & 0 & 0 & 0 \\
Fair & $56-65$ & 7 & 21.8 & 6 & 18.7 \\
Poor & $36-55$ & 22 & 68.7 & 23 & 71.9 \\
Very poor & $00-35$ & 3 & 9.4 & 3 & 9.4 \\
\hline Total & & 32 & 100 & 32 & 100 \\
\hline
\end{tabular}

Table 1 illustrates that most of the students in pretest were in poor category. The aggregate percentage of pretest categorized as very poor achiever was 3 students (9.4\%). While in posttest illustrates that the students' achievement improved after giving the treatment that can be seen on the table below:

Table 2: The Frequency and Percentage of the Students' Reading Comprehension Achievement in Posttest.

\begin{tabular}{lccccc}
\hline \multicolumn{1}{c}{ Classification } & Range of score & \multicolumn{2}{c}{ Experimental Group } & \multicolumn{2}{c}{ Control Group } \\
\hline Excellent & & $\mathrm{F}$ & $\%$ & $\mathrm{~F}$ & $\%$ \\
Very good & $96-100$ & 2 & 6.3 & 0 & 0 \\
Good & $86-95$ & 14 & 43.8 & 0 & 0 \\
Fairly good & $76-85$ & 10 & 31.2 & 1 & 3.1 \\
Fair & $66-75$ & 6 & 18.7 & 12 & 37.5 \\
Poor & $56-65$ & 0 & 0 & 12 & 37.5 \\
Very poor & $36-55$ & 0 & 0 & 7 & 21.9 \\
\hline Total & $00-35$ & 0 & 0 & 0 & 0 \\
\hline
\end{tabular}

Table 2 illustrates the improvement of frequency and rate percentage of the students' scores on reading comprehension in post-test. From this table can be seen that the students' achievement in experimental group and control group improved after treatment. In experimental group, the score of the students tend to spread from fairly good to excellent category. While in control group, the students' scores were spread dominantly in poor to good category. No one student was categorized as good and excellent.

The aggregate percentage of posttest categorized as high achiever was 26 students $(81.2 \%)$. The score distribution for all students reading comprehension in posttest showed the difference from the pretest. The aggregate percentage of posttest categorized as high achiever was 81.2 percent (26 students). While in control group, no one of them gained very good score to excellent. But it can be improved their critical level. It can be concluded that the use of translanguaging approach can improve the students' reading comprehension in term of literal, inferential, and critical comprehension level.

Table 3: The mean score of students' reading comprehension

\begin{tabular}{lcccc}
\hline \multicolumn{1}{c}{ Groups } & \multicolumn{2}{c}{ Mean score } & \multicolumn{2}{c}{ Standard deviation } \\
\hline & Pretest & Posttest & Pretest & Posttest \\
Experimental & 46.66 & 84.16 & 8.59 & 8.07 \\
Control & 46.66 & 62.91 & 8.25 & 8.02 \\
\hline
\end{tabular}


Table 3 indicates that there are difference of students' score and standard deviation of students' comprehension in reading. The data analysis shows the students' mean score for both group experimental and control was low or it classified as poor. And it improved after giving the treatment through translanguaging approach. Below is the T-Test result as whole as pretest and posttest of students' reading comprehension:

Table 4: The Probability Value of T-Test of the Students' Achievement on Students' Reading Comprehension in Pretest and Posttest

\begin{tabular}{lcccc}
\hline & \multicolumn{1}{c}{$\mathrm{T}$} & $\begin{array}{c}\text { 2 Tailed } \\
\text { Value }\end{array}$ & $(\alpha)$ & Remarks \\
\hline $\begin{array}{l}\text { Control Pretests and } \\
\text { Experimental Pretest }\end{array}$ & 0.000 & 1.00 & 0.05 & $\begin{array}{l}\text { There was } \\
\text { No Different }\end{array}$ \\
\hline $\begin{array}{l}\text { Control Posttest and } \\
\text { Experimental Posttest }\end{array}$ & 9.189 & 0.00 & 0.05 & $\begin{array}{l}\text { Significantly } \\
\text { Different }\end{array}$ \\
\hline
\end{tabular}

The result of data analysis as summarized in table 4.16 on pretest and posttest of control and experimental group, the researcher found that the Probability value (1.00) is higher than the level of significance at $t$-table $(0.05)$ and the degree of freedom 62 . The data also showed that the t-count value was smaller than t-table $(1.000<2.000)$. It indicated that the alternative hypothesis $\left(\mathrm{H}_{1}\right)$ was rejected and the null hypothesis $\left(\mathrm{H}_{0}\right)$ was accepted. In the other word, there was no significant difference between the students reading comprehension in pretest and posttests before the treatment. After treatment, the researcher found that the Probability value $(0.00)$ was smallest than the level of significance at t-table (0.05) and the degree of freedom 62. The data also showed that the $\mathrm{t}$-count value was higher than $\mathrm{t}$-table $(9.189<2.000)$. It indicated that the alternative hypothesis $\left(\mathrm{H}_{1}\right)$ was accepted and the null hypothesis $\left(\mathrm{H}_{0}\right)$ was rejected. In the other word, there was significant difference between the students reading comprehension in pretest and posttest after giving the treatment through translanguaging approach. It means that the application of translanguaging in teaching reading can increase the students' Arabic reading comprehension, but the most that can increased in learning is literal because of the answer already can be found by the students on the reading text.

Based on the data above, the researchers concluded that the data of posttest as the final result gave significant improvement. It can be summarized that the use of translanguaging approach was able to give greater contribution in teaching Arabic reading comprehension or the use of translanguaging approach in teaching Arabic reading comprehension was effective.

\section{E. DISCUSSION}

The description of the data collected through test as explained in the previous section shows that the students' reading comprehension improves enormously. It is also proved by the mean score rate of the students' pretest and posttest of experimental group. The mean score of pretest and posttest of experimental group was 46.66 to 84.16 while the mean score of pretest and posttest of control group was 46.66 to 62.91 . The difference score between both groups was 21.25. It means that students' score in experimental group was greater than students' score in control class, on the other words, 
can be stated that the use of translanguaging approach gives far the better effect in learning reading than conventional way.

Both translanguaging approach and conventional method are able to be applied in teaching reading and evolve the students' achievement of reading, but then, using of translanguaging approach in teaching reading comprehension more develops meaningfully students' ability than the conventional one. Translanguaging could change the students' reading comprehension better than before. So it can be inferred statistically based on t-test value that translanguaging approach is more effective in developing students' comprehension of literal, inferential and critical in reading skill, in other words, it could increase the students' learning reading comprehension and is more effective than conventional method.

Arabic reading comprehension through translanguaging approach is also effective to be used in learning critical reading comprehension, in other words, can be said that the students have experienced an increase the ability of in literal, inferential, and critical reading comprehension. It is in line with some of the statements of several experts, according to Wei (2016) is effective in improving process and outcome of learning, The same opinion was expressed by Saputra (2015) "just as in jigsaw puzzle, each piece-each students' part is essential for the completion and full understanding of the final product. If each student's part is essential, then each student is essential; and that is precisely what makes this strategy so effective. It is also supported by translanguaging approach that make it possible for the students to work together to complete the assignment on their own. Therefore, "each member of a team is responsible not only for learning what is taught but also for helping teammates learn, thus creating an atmosphere of achievement". Also it is supported by statement of Lewis et al., (2012) stated that students work through the assignment until all group members successfully understand and complete it".

\section{F. CONCLUSION}

Based on the research findings and discussion in the previous, the researchers draw conclusion in the following statement. The use of translanguaging approach in learning Arabic reading comprehension at the second semester students of Indonesian Education Department, Universitas Iqra Buru improves the students' ability of Arabic reading comprehension is better than conventional method where the mean score of posttest of the experimental group was higher than the control group $(84.16>62.91)$. Thus, the use of translanguaging approach was effective and contributed $21.25 \%$ to improve students' Arabic reading comprehension. Besides, all the three levels of comprehension improved after the treatment, those are (a) The literal comprehension got the highest improvement is 92.19> 76.69 with the difference score between both groups was 12.5 or $12.5 \%$; (b) The inferential comprehension which got $83.75>66.25$, with the difference score between both groups was 17.05 or $17.05 \%$; and (c) the critical comprehension which got $76.56>42.81$ with the difference score between both groups was 33.75 or $33.75 \%$.

It is suggested that the teaching literal, inferential and critical levels of Arabic reading comprehension should be continually implemented to the students. The teacher especially Arabic teacher should be more creative to use the suitable technique for learning Arabic, the technique that can make all students can participate in the classroom, so that not only some students are able to understand lesson given well, but also all of them, and going to be real, if all of students are involved in the learning 
process. Due to its limitation, the present research was just held four times for treatments, so it was not maximized. Therefore, it is suggested that there should be a further research with more exercise on skill to be developed.

\section{References}

Abubakar, B., Atmowardoyo, H., \& Korompot, C. A. (2017). The Challenges in Undertaking English Speech Training Program at an Islamic Boarding School: A Study of Students' Perspectives. ELT WORLDWIDE, 4(2), 125-137.

Amri, M., Tahir, S. Z. A. B., \& Ahmad, S. (2017). The Implementation of Islamic Teaching in Multiculturalism Society: A Case Study at Pesantren Schools in Indonesia. Asian Social Science, 13(6), 125-135.

Bin Tahir, S. Z. (2015). Multilingual Education in Pesantren Context. Yogyakarta: Deepublish.

Bin-Tahir, S. Z., \& Rinantanti, Y. (2016). Multilingual Lecturers' Competence in English Teaching at the University of Iqra Buru, Indonesia. Asian EFL Journal, 5, 79-92.

Bin Tahir, S. Z. (2017). Multilingual teaching and learning at Pesantren Schools in Indonesia. Asian EFL Journal, 89, 74-94.

Bin-Tahir, S. Z., Atmowardoyo, H., Dollah, S., \& Rinantanti, Y. (2017). Multilingual learning program: pesantren students' perceptions of the multilingual simultaneous-sequential model. JELE (Journal Of English Language and Education), 3(2), 44-53.

Bin-Tahir, S. Z., Bugis, R., \& Tasiana, R. (2017). Intercultural Communication of a Multicultural Family in Buru Regency. Lingual: Journal of Language and Culture. Volume 9(2). 8-15.

Canagarajah, S. (2011). "Codemeshing in Academic Writing: Identifying Teachable Strategies of Translanguaging". The Modern Language Journal. 95 (3): 401417. doi: 10.1111/j.1540-4781.2011.01207.

Carrillo, L. W. (1976). Teaching reading: A handbook. St. Martin's Press.

Cruz-Ferreira, M. (2010). Multilinguals are...? London: Battlebridge Publications.

Duarte, J. (2016). Translanguaging in mainstream education: a sociocultural approach. International Journal of Bilingual Education and Bilingualism. DOI:10.1080/13670050.2016.1231774. Accessed on June 2017 from https://www.tandfonline.com/doi/full/10.1080/13670050.2016.1231774.

Edi, E., Basri, W., \& Syarifuddin, S. (2017). Investigating the Students' Strategies in Developing Intercultural Communicative Competence (ICC) Model in Indonesia University Context. Journal of Language Teaching and Research, 8(6), 1234-1240.

Edwards, J. (1994). Multilingualism. London: Routledge.

García, O., \& Wei, L. (2014). Translanguaging and education. In Translanguaging: Language, bilingualism and education (pp. 63-77). Palgrave Macmillan, London.

Gay, L.R. (2006). Educational Research: Competencies for Analysis and Application. Second Edition. Ohio: Charles E. Marril Publishing Co.

Harmer, J. (2001). The practice of English language teaching. London/New York.

Hornby, G. (1995). The Code of Practice: boon or burden?. British Journal of Special Education, 22(3), 116-119. 
Irwansyah, D. (2013). Pendidikan Multikultural dan Pengajaran Bahasa Asing. ADDIN, Vol. 7(1). P.p. 1-18.

Kemp, C. (2009). Defining multilingualism. In L. Aronin \& B. Hufeisen (Eds.), The exploration of multilingualism. Amsterdam, The Netherlands: John Benjamins. pp. 11-26.

Lewis, G., Jones, B., \& Baker, C. (2012). Translanguaging: Origins and development from school to street and beyond. Educational Research and Evaluation, 18(7), 641-654.

McArthur, T. (ed). (1992). The Oxford Companion to the English Language. Oxford: OUP.

Pang, E. S., Muaka, A., Bernhardt, E. B., \& Kamil, M. L. (2003). Teaching reading (Vol. 12). Brussels: International Academy of Education.

Saidna, Z., Tahir, B., Haryanto, A., Syarifuddin, D., \& Yulini, R. (2017). Multilingual Instructional Model of Pesantren Schools in Indonesia. Journal of Language Teaching and Research, 8(6), 1210-1216.

Saputra, W. A., \& Atmowardoyo, H. (2015). Translanguaging In Indonesian University Classroom Context: A Discourse Analysis At Muhammadiyah University In South Sulawesi. ELT WORLDWIDE, 2(1), 42-62.

Tahir, B., \& Zulfiqar, S. (2015). Multilingual Behavior of Pesantren IMMIM Students in Makassar. Asian EFL Journal, 86, 45-64.

Tahir, S. Z. B., \& Hanapi, H. (2017). Lecturers' Method in Teaching Speaking at the University of Iqra Buru. International Journal of English Linguistics, 7(2), 7386.

Vildomec, V. 1(963). Multilingualism. Leyden: A.W. Sythoff.

Wei, L. (2017). Translanguaging as a Practical Theory of Language. Applied Linguistics, Volume 39, Issue 1, 1 February 2018, Pages 9-30, https://doi.org/10.1093/applin/amx039. 